\title{
Trying to shake Japan's faith in forecasts
}

\section{Tokyo}

THE future of Japan's huge national research effort to predict earthquakes, which has run for nearly three decades and consumed thousands of millions of yen, is being questioned for the first time by scientists here.

Japan is practically the only country in which earthquake mitigation and hazard reduction takes a back seat to predicting the next big one. Yesterday (8 April), scientists who are critical of that emphasis were expected to have their first chance to modify its course at a meeting in Kyoto of a newly formed subcommittee of the Science Council of Japan, an academic advisory body to the government. But even they are not optimistic about their chances of success.

Standing firm against any attempts to open up the system to outsiders are a handful of senior seismologists, who have been in the earthquake prediction business since the 1960 s. This group have effectively by-passed external review by holding a series of closed meetings over the past few months to draw up their own internal review of the research for the government, in much the same way as they have done for the past 30 years. The review process now unfolding provides insight into how small groups of powerful academics can exert enormous influence over government funding of research in Japan.

The earthquake research programme is one of Japan's largest and oldest national research project. In the past 17 years, according to government statistics, the programme has consumed almost 100,000

million yen (US\$700 million), and currently receives about $\$ 50$ million a year (see figure). But, the government figures are deceptively low, because they do not include the salaries of the 500 or so researchers in various government research organizations who are involved in earthquake prediction.

Last year, US geophysicist Robert Geller of Tokyo University sent shock waves through the earthquake prediction

Steady funding, but to what end?

All figures in millions

$\begin{array}{ccc} & \begin{array}{c}\text { Earthquake } \\ \text { prediction }\end{array} & \begin{array}{c}\text { Volcano } \\ \text { prediction }\end{array} \\ 1986 & ¥ 5,339 \text { (US\$40) } & ¥ 488 \text { (US\$4) } \\ 1987 & 5,320 & 595 \\ 1988 & 5,701 & 620 \\ 1989 & 6,020 & 674 \\ 1990 & 6,192 & 731 \\ 1991 & 6,669 & 698 \\ \text { Total } & ¥ \mathbf{3 5 , 2 4 1} & \mathbf{3 , 8 0 6} \\ & \text { (US\$261) } & \text { (US\$28) }\end{array}$

community in Japan by arguing (Nature, 352,275 ; 1991) that earthquake prediction is beyond the present capabilities of science and that Japan's earthquake prediction programme should undergo thorough external review. Following Geller's comments, many Japanese scientists have started to criticise the present system openly. The most recent is Seiya Uyeda, a professor of both Tokai University and Texas A \& M University in the United States.
In February's issue of the semi-government publication 'Japanese Scientific Monthly' (Gakujutsu Geppo), Uyeda describes the growing disillusionment among Japan's seismologists with the present state of prediction research in Japan, which consists mainly of collecting huge amounts of data in the hope that some reliable 'precursor' of earthquakes will be found. That approach has largely been abandoned in the United States and elsewhere after the failure in the 1970s to find such precursors. Uyeda suggests that perhaps the only way to reinvigorate the research community in Japan is to create "a crisis" and to cut the government budget for the programme to "one-tenth its present size".

The new science council subcommittee, which met for the second time this week in Kyoto, was set up last October partly in response to such criticisms. The 27-man subcommittee includes Geller and several other critics, as well as senior leaders of the earthquake prediction programme. At the urging of the critics, the agenda for this week's meeting calls for a new "blueprint" for earthquake prediction to replace the one that set the present programme on its course in the 1960 s.

The discussions in Kyoto, however, are not expected to change the course of earthquake research in Japan. A smaller but much more powerful eight-man committee of senior seismologists, many of whom are also on the new Science Council subcommittee, have met six times behind closed doors since October and have already produced a draft review of the earthquake prediction programme, now in its sixth

\section{Vulcanologists seek to understand processes}

Tokyo

ALTHOUGH Japan's earthquake prediction programme may not have much chance of undergoing significant change (see above), the same is not true for efforts to modify the study of volcanic eruptions.

One difference is that the chairman of the review committee of the volcanic prediction programme, Yoshiaki Ida of the Earthquake Research Institute of Tokyo University, is comparatively young and has strong views about where the field should be headed. He would like to see less emphasis on the empirical collection of data, and more effort spent on trying to understand the basic processes of volcanic eruption. That might include a search for magma chambers and the migration of magma using seismic techniques, as well as modelling such processes. Such an understanding, he believes, could mean a much more systematic approach to prediction rather than the present way of "just trying to get precursors without physical reason".

Ida would also like to see Japan's vulcanologists spend more time communicating with the public. Japan's volcanic prediction committee has come under severe public criticism in recent years for its terse, uninformative and sometimes misleading statements about volcanic eruptions (Nature $\mathbf{3 5 1}$, $511 ; 1991)$. In contrast, Ida says, the Philippine government preceded last year's eruption of the Pinatubo volcano by distributing videos showing the dangers of pyroclastic flows. It also issued public warnings, of increasing severity, in the weeks leading up to the actual eruption.

Ida says he does not expect "drastic" change in Japan's volcanic eruption prediction programme because his review committee is "rather conservative". But he does see hope for a "better trend". 